\title{
Influence of the method of production of eggs on the daily intake of polycyclic aromatic hydrocarbons and organochlorine contaminants: An independent study in the Canary Islands (Spain)
}

\author{
Octavio P. Luzardo*, Ángel Rodríguez-Hernández, Yohana Quesada-Tacoronte, Norberto Ruiz-Suárez, \\ Maira Almeida-González, Luis Alberto Henríquez-Hernández, Manuel Zumbado, Luis D. Boada \\ Toxicology Unit, Department of Clinical Sciences, Health Sciences Faculty, University of Las Palmas de Gran Canaria, P.O. Box 550, 35080 Las Palmas de Gran Canaria, Spain
}

\section{A R T I C L E I N F O}

\section{Article history:}

Received 29 May 2013

Accepted 3 August 2013

Available online 11 August 2013

\section{Keywords:}

Organochlorine pesticides

Polychlorinated biphenyls

Polycyclic aromatic hydrocarbons

Hen eggs

Organic eggs

\begin{abstract}
A B S T R A C T
Analysis of 16 polycyclic aromatic hydrocarbons (PAHs), 20 organochlorine pesticides (OCPs) and 18 polychlorinated biphenyls (PCBs) were performed on eggs from three different production types (conventional, free-run and organic) collected from the markets of the Canary Islands (Spain). Unlike other studies we did not found differences in the content of PCBs or OCPs of eggs in relation to its production type. Median $\sum$ OCPs content was $3.87 \mathrm{ng} \mathrm{g}^{-1}$ fat, being dieldrin, dicofol, hexachlorobenzene, $p, p^{\prime}$-DDE and $p, p^{\prime}$-DDT the most frequently detected. Median $\sum$ PCBs value was $3.93 \mathrm{ng} \mathrm{g}^{-1}$ fat, with $79.9 \%$ of this amount coming from the marker PCBs. Two samples, one free-run and one organic, greatly exceeded the current European Commission (EC) limit of $2.5 \mathrm{pg} \mathrm{TEQ}_{\mathrm{PCDD} / \mathrm{F}} \mathrm{g}^{-1}$ lipid, but the rest were well below of this limit. The concentrations of PAHs in conventionally produced eggs were almost 4 times higher than in free-run or organic eggs. Mean dietary intake estimates of the organochlorine contaminants based on consumption of eggs, regardless of the type chosen, is negligible for the Canary Islands' population. However, the median dietary intake estimates of PAHs greatly depend on the type of eggs chosen, being much lower when free-run and organic eggs are consumed.
\end{abstract}

(c) 2013 Elsevier Ltd. All rights reserved.

\section{Introduction}

Persistent organic pollutants (POPs) are toxic chemicals that are resistant to degradation in the environment and biota. Over the last 30 years a number of these substances have been highlighted as a cause for concern (Boada et al., 2012; Casals-Casas and Desvergne, 2011; Dickerson et al., 2011; Dorgan et al., 1999; Knerr and Schrenk, 2006; Ribas-Fito et al., 2001; Samanta et al., 2002) and have been the subject of extensive study and international regulation. Due to their stable structure and lipophilic character POPs such as organochlorine pesticides (OCPs), polychlorinated biphenyls (PCBs) and polycyclic aromatic hydrocarbons (PAHs) tend to concentrate and magnify in the food chain particularly associated with fat. It is well accepted that food consumption is the main way of non-occupational human exposure to these contaminants compared to other ways such as inhalation and dermal contact. The ingestion of contaminated food contributes more than $90 \%$ to the total exposure and foodstuffs of animal origin are recognized as one of the main contributors (Almeida-Gonzalez et al., 2012; Luzardo et al., 2012; Marti-Cid et al., 2008; Mezzetta et al., 2011).

\footnotetext{
* Corresponding author. Tel.: +34 928453 472; fax: +34 928451416.

E-mail address: operez@dcc.ulpgc.es (O.P. Luzardo).
}

The laying hen eggs are one of the main sources of protein in human food all over the world. During the last decades in most of the countries the major production method of this food item has been by means of the housing of the hens in battery cages, without outdoor access. In parallel, in the last years the demand of eggs from alternative production methods, such as free-run production where animals have access to the barn floors, or organic production with strict regulations regarding the feed and welfare of the animals, have steadily increased in Europe (Hsu et al., 2010). The eggs produced by these alternative methods are perceived by many consumers as a better choice because of their healthier nature, better nutritional qualities and also because these production methods are more respectful with the animal wellness (Van Overmeire et al., 2006). Independently of the production method, the transfer of POPs into hen eggs, especially into yolk bound to its lipidic fraction, has been widely documented for OCPs, PCBs and PAHs (Bargar et al., 2001; Fournier et al., 2010, 2012). For this reason securing the quality of hen eggs is an important issue for human food safety, and specific studies are regularly performed in different regions of the planet to determine concentrations of POPs in this and other foods of primary interest.

Several studies have demonstrated that the production method of the eggs could influence their content in organochlorine 
contaminants. Paradoxically, some of these studies point to the possibility that organic and free-run eggs could accumulate higher quantities of dioxins (Hsu et al., 2010; Pussemier et al., 2004), PCBs, and OCPs (Van Overmeire et al., 2006; Windal et al., 2009) than conventionally produced ones, mainly linked to a higher degree of consumption of soil and worms or other insects by the hens that have outdoor access (Kijlstra et al., 2007), whereas other studies do not find such differences (Rawn et al., 2012). However, to our knowledge, comparative studies have not been performed regarding the PAHs content of eggs in relation to the production method, and how this fact could influence the consumer's intake of these contaminants.

In the present study, 12 egg composites of each of three production methods (conventionally caged laying hens, free-run, and organic) were collected in 2012 from supermarkets and stores in the Canary Islands (Spain). The goal was to determine the concentrations of OCPs, PCBs and PAHs and to establish whether relative differences in POPs concentrations occurred between the different types of eggs marketed, with the objective of estimating the exposure in humans to these contaminants through the consumption of eggs depending on the production type chosen.

\section{Materials and methods}

\subsection{Sampling}

In this study, a total of 36 composites of egg samples were processed from the same number of packages of 6 units of medium size eggs (53-63 g). The packages were randomly acquired from supermarkets and also stores specialized in organic food of the Canary Islands (Spain). We bought 12 packages of six different brands of each of the three production methods included in this study: conventionally produced eggs (battery caged hens), free-run eggs, and organic eggs. All the samples were acquired within the last week of November and the first of December 2012. $100 \%$ of the samples were locally produced. At the arrival to the laboratory the samples were immediately prepared. Yolks were separated from the whites and each sample was made up by combining the yolks of the eggs of the same package in a single composite. The whites were discarded since their fat content was unappreciable. The 36 yolk composites were frozen at $-18^{\circ} \mathrm{C}$ until ready for analysis.

The lipid content of the samples was determined in triplicate by the Gerber method with a butyrometer (with a graduation scale of $0-40 \%$ ) to obtain the final lipid-corrected values. There were no statistically significant differences in the fat content of the composites being the average fat content of $11.6 \%$ (referred to the whole egg, $58 \mathrm{~g}$ average weight).

\subsection{Chemicals and reagents}

Dichlorometane, hexane, ethyl acetate and cyclohexane were of the highest purity available $(>99.9 \%$ ) and purchased from Fisher Scientific (Leicestershire, United Kingdom). Ultrapure (UP) water was produced from a Milli-Q Gradient A10 (Millipore, Molsheim, France). Diatomaceous earth was purchased from SigmaAldrich (St. Louis, USA). Bio-Beads SX-3 were purchased from BioRad Laboratories (Hercules, USA). Standards of OCPs, PCB congeners, the surrogates (PCB 202, p, $p^{\prime}$-DDE-d8 and phenanthrene-d10) and internal standards (ISs, tetrachloro-mxylene and heptachloro epoxide cis), were purchased from Dr Ehrenstorfer, Reference Materials (Augsburg, Germany). Standards of PAHs were purchased from Absolute Standards, Inc. (Connecticut, USA). All standards were neat compounds (purity from 97\% to 99.5\%). Stock solutions of each compound at $1 \mathrm{mg} / \mathrm{mL}$ were prepared in cyclohexane and stored at $-20^{\circ} \mathrm{C}$. Diluted solutions from $0.05 \mathrm{ng} / \mathrm{mL}$ to $100 \mathrm{ng} / \mathrm{mL}$ were used for calibration curves.

\subsection{Analytes of interest}

A total of 54 analytes belonging to three relevant groups of POPs were selected for this study. The 20 OCPs and metabolites included were the diphenyl-aliphatics (methoxychlor, $p, p^{\prime}$-DDT, $p, p^{\prime}$-DDE, $p, p^{\prime}$-DDD and dicofol); the persistent and bioaccumulative contaminant hexachlorobenzene (HCB); the four isomers of hexachlorocyclohexane ( $\alpha-, \beta-, \delta-$, and $\gamma-\mathrm{HCH})$; the cyclodienes heptachlor, dieldrin, aldrin and endrin, chlordane (cis- and trans-isomers) and mirex; endosulfan ( $\alpha$ - and $\beta$-isomers) and endosulfan sulfate. With respect to the PCBs we decided to include a total of 18 congeners: the dioxin-like congeners (IUPAC numbers\# 77, 81, 105, 114, 118, $123,126,156,157,167,169$ and 189), and the six marker congeners of non-dioxinlike PCBs (IUPAC numbers\# 28, 52, 101, 138, 153 and 180). Finally, we also included in the suite of analytes the list of the 16 EPA priority PAHs that is often targeted for measurement in environmental samples (naphthalene, acenaphtylene, acenaphtene, fluorene, phenanthrene, anthracene, fluoranthene, pyrene, benz $[a]-$ anthracene, benzo[ $b]$ fluoranthene, benzo[k]fluoranthene, benzo[ $a]$ pyrene, indeno[1,2,3-c,d]pyrene, dibenz[ $a, h]$ anthracene and benzo[g,h,i]perylene).

\subsection{Extraction and clean-up procedure}

Because of the known fact that the contaminants included in this study are totally lipid-soluble and therefore found in the lipid fraction of food items, we only processed the yolks of the eggs since the lipid content of the whites is extremely low, next to $0.10 \mathrm{~mL}$ of the composite of yolks formed from the eggs of each package were spiked with the $10 \mathrm{ppm}$ surrogates mix in acetone to yield a final concentration of $100 \mathrm{ppb}$ and mixed with $30 \mathrm{~g}$ of diatomaceous earth to absorb all the humidity. The method of extraction and clean up followed that recommended by the European Standard for the determination of pesticides and PCBs in fatty food (EN, 1996a,b), and whose validity has been previously proven in our laboratory for fatty foods (Almeida-Gonzalez et al., 2012; Luzardo et al., 2012). This method combines an automated Soxhlet extraction method (FOSS Soxtec Avanti 2055) with a purification step using gel permeation chromatography (GPC). This method gives acceptable recoveries that ranged between $74.5 \%$ and $104.7 \%$. There were no need of additional clean-up steps and the $1 \mathrm{~mL}$-extracts in cyclohexane obtained at the end of the GPC were used for the gas chromatography/triple quadrupole mass spectrometry (GC-MS/MS) analysis.

\subsection{Procedure of chemical analysis}

Gas chromatography analyses of 54 contaminants, 3 surrogates and 2 ISs were performed in a single run on a Thermo Trace GC Ultra equipped with a TriPlus Autosampler and coupled to a Triple Quadrupole Mass Spectrometer Quantum XLS (Thermo Fisher Scientific Inc., Waltham, MA, USA), using appropriate internal standards (ISs) as previously described (Camacho et al., 2012, 2013). We have used as ISs a mixture of tetrachloroxylene and heptachloro epoxide cis that was prepared at $1 \mathrm{ppm}$ in cyclohexane, and $20 \mu \mathrm{L}$ were added to each $1 \mathrm{~mL}$-extract, just before the GC-MS/MS analysis.

\subsection{Dietary intake estimates and calculations}

The exposure assessment was calculated by multiplying the respective concentrations of contaminants in eggs (median values) by the amount of fat contained in the average daily egg consumption by adults ( 18 years old and above, average weight $70.1 \mathrm{~kg}$, mean daily egg consumption $25.1 \mathrm{~g}$ ), youngsters (11-17 years old average weight $54.5 \mathrm{~kg}$, mean daily egg consumption $30.8 \mathrm{~g}$ ), or children (610 years old, average weight $30.4 \mathrm{~kg}$, mean daily egg consumption $22.6 \mathrm{~g}$ ) from the Canary Islands. Exposures were assessed for all the contaminants, individually considered and also grouped in different forms. For calculations, when the concentration of a given contaminant was below the limit of detection (LOD), the value was assumed to be that LOD (upper bound approach). Consumption data of eggs by the population of the Canary Islands were obtained from the Canary Islands Nutritional Survey (Serra Majem et al., 2000).

In this work we expressed the total value of OCPs residues ( $\sum$ OCPs) as the sum of the 20 OCPs and metabolites measured; the total value of DDTs ( $\sum$ DDT) as the sum of the measured values of $p, p^{\prime}$-DDT, $p, p^{\prime}$-DDE and $p, p^{\prime}$-DDD; the total value of $\mathrm{HCH}$ residues $\left(\sum \mathrm{HCH}\right)$ as the sum of the $4 \mathrm{HCH}$ isomers measured $(\alpha-, \beta-$ $\delta-$, and $\gamma-\mathrm{HCH}$ ); and the total value of cyclodienes residues ( $\sum$ cyclodienes) as the sum of aldrin, dieldrin, endrin, cis-chlordane, trans-chlordane, and heptachlor. Similarly we expressed the total value of $\mathrm{PCB}$ residues ( $\sum \mathrm{PCBs}$ ) as the sum of the 18 PCB congeners measured; in addition the six congeners considered as markers of environmental contamination by PCBs (\#28, 52, 101, 138, 153 and 180) were also considered as a group ( $\sum \mathrm{M}-\mathrm{PCBs}$ ); and total value of dioxin-like PCBs ( $\sum \mathrm{DL}-\mathrm{PCBs}$ ) was also considered as the sum of the measurements of the 12 individual dioxinlike congeners (\#77, 81, 105, 114, 118, 123, 126, 156, 157, 167, 169 and 189). Additionally, we estimated the potential toxicity (in terms of toxic equivalence to dioxins; TEQs) for the DL-PCBs using the toxic equivalency factors (TEF) as revised by the World Health Organization (WHO) in 2005 (Van den Berg et al., 2006). We expressed the total TEQs ( $\sum$ TEQs) as the sum of TEQs individually obtained from the DL-PCBs. Finally we considered the total content of PAHs ( $\mathrm{PPAHs}$ ) as the sum of the values of the 16 US-EPA compounds included in this study and also, following the EFSA recommendations (EFSA, 2008), the sum of the 8 compounds for which there are evidences of carcinogenicity ( $\mathrm{PAH} 8$ ): benz $[a]$ anthracene, benzo[a]pyrene, benzo[b]fluoranthene, benzo[ $k]$ fluoranthene, benzo[g,h,i]perylene, chrysene; dibenz[ $a, h]$ anthracene; and indeno[1,2,3-c,d]pyrene.

\subsection{Statistical analyses}

Database management and statistical analyses were performed using PASW Statistics v. 20.0 (SPSS Inc., Chicago, USA). The distribution of the variables included in this study was evaluated through Kolmogorov-Smirnov test. The concentration of the contaminants included in this study did not follow a normal distribution; therefore, the results are expressed in terms of the median, and range (values minimum and maximum). Differences of contaminants among groups were tested 
with the non-parametric Mann-Whitney U-test and Kruskal Wallis test. The categorical variables are presented as percentages and were compared between variables with the Chi-square test. A $P$ value of less than 0.05 (two-tail) was considered to be statistically significant.

\subsection{Quality control}

The recoveries of the 54 analytes and surrogates were acceptable with this method since in all the cases were above of $72 \%$. All the individual measurements were corrected by the recovery efficiency for each analyte. All the measurements were done in triplicate and the values used for calculations were the mean of the three data. In each batch of samples two controls were included every 12 samples: a reagent blank consisting on a vial containing only cyclohexane; and an internal laboratory quality control (QC) consisting on melted butter spiked at $20 \mathrm{ng} \mathrm{g}^{-1}$ of each of the analytes that was processed with the same method than the samples. The batch analyses were considered valid when the values of the analytes in the QC were within a $10 \%$ of deviation of the theoretical value.

\section{Results and discussion}

\subsection{Occurrence of OCP residues in egg yolk samples}

Researchers of other European countries have reported that the eggs that are produced from hens that have outdoor access (free-range, free-run, home-produced, and organic) usually exhibit higher levels of OCPs than those produced from caged hens, (Van Overmeire et al., 2006; Windal et al., 2009), and also reported a high degree of contamination by these substances, surpassing in many cases the maximum residue levels (MRLs) established for these contaminants. This situation have not been confirmed in our study, where we have found similar results on the number of residues detected, frequency and concentrations of these contaminants, with only small differences among groups. Besides, the total amount of OCPs found in our samples is much lower than those found recently in other countries in Europe (Polder et al., 2010; Windal et al., 2009), being as low as $0.95 \mathrm{ng} \mathrm{g}^{-1}$ in free-run eggs (median value, Table 1). Nevertheless, it should be taken into account that the Canary Islands, still being part of Europe, are an archipelago that is geographically located very far from the European continent, and that eggs consumed in this territory, unlike other primary food supplies, are almost $100 \%$ locally produced. For this reason our results could be reflecting a lower degree of environmental contamination by these organochlorine contaminants of this region.

In any case, as expected, our results showed that all analyzed samples (100\% of the eggs) had small but quantifiable amounts of OCP residues. In all the cases the concentrations found in our study were well below the MRLs (EC, 2005) and also below of the levels published in recent studies in Europe. The number of OCP residues detected was almost the same in all three types of eggs, with an average of 7 residues per composite, but the frequency of detection was different depending on the production type. As shown in Table 1 the more frequent OCP residues in conventionally produced and free-run eggs were dieldrin, followed by dicofol and the $\mathrm{HCH}$ isomers $\beta$ and $\gamma$, whereas in organic eggs the most frequently detected residue was $p, p^{\prime}$-DDE, that was present in $83.33 \%$ of the composites of this form of producing eggs. Also the concentrations of this contaminant and its parent product, $p, p^{\prime}$-DDT, were slightly higher in organic egg composites (median $\sum$ DDT values $=0.62 \mathrm{ng} \mathrm{g}^{-1}$ fat vs. $0.38 \mathrm{ng} \mathrm{g}^{-1}$ fat and $0.22 \mathrm{ng} \mathrm{g}^{-1}$ fat), reaching in some of the samples values of around $10 \mathrm{ng} \mathrm{g}^{-1}$ fat. These higher concentrations of persistent contaminants in organic eggs is not a surprising result since some authors have pointed to the possibility that laying hens under organic production system, that spend many hours a day ranging outdoors, eating soil and soil's creatures (worms and other insects), are more exposed to environmental pollutants than those that are caged or in outdoor facilities with barn floor, where the possibility of eating soil does not exist (Van Overmeire et al., 2006; Windal et al., 2009). However, it should be highlighted that the highest values found in our study are still very far from the maximum level of $500 \mathrm{ng} \mathrm{g}^{-1}$

Table 1

Levels of organochlorine pesticides detected in composite samples of hen egg yolks from three production methods ( $n=12 /$ each).

\begin{tabular}{|c|c|c|c|c|c|c|c|c|c|c|c|}
\hline \multirow[t]{2}{*}{ Compound } & \multicolumn{3}{|c|}{ Conventional production } & \multicolumn{3}{|c|}{ Free-run production } & \multicolumn{3}{|c|}{ Organic production } & \multirow[t]{2}{*}{$P^{a}$} & \multirow[t]{2}{*}{$P^{\mathrm{b}}$} \\
\hline & $\begin{array}{l}\text { Median } \\
\left(\mathrm{ng} \mathrm{g}^{-1}\right)\end{array}$ & $\begin{array}{l}\text { Frequency } \\
(\%)\end{array}$ & $\begin{array}{l}\text { Detection } \\
\text { range } \\
\left(\mathrm{ng} \mathrm{g}^{-1}\right)\end{array}$ & $\begin{array}{l}\text { Median } \\
\left(\mathrm{ng} \mathrm{g}^{-1}\right)\end{array}$ & $\begin{array}{l}\text { Frequency } \\
\text { (\%) }\end{array}$ & $\begin{array}{l}\text { Detection } \\
\text { range } \\
\left(\mathrm{ng} \mathrm{g}^{-1}\right)\end{array}$ & $\begin{array}{l}\text { Median } \\
\left(\mathrm{ng} \mathrm{g}^{-1}\right)\end{array}$ & $\begin{array}{l}\text { Frequency } \\
(\%)\end{array}$ & $\begin{array}{l}\text { Detection } \\
\text { range } \\
\left(\mathrm{ng} \mathrm{g}^{-1}\right)\end{array}$ & & \\
\hline Hexachlorobenzene & 0.03 & 33.33 & n.d. -0.06 & 0.02 & 25.00 & n.d. -0.02 & 0.02 & 33.33 & n.d. -0.03 & & \\
\hline$\alpha-\mathrm{HCH}$ & n.d. & n.d. & n.d. & n.d. & n.d. & n.d. & n.d. & n.d. & n.d. & & \\
\hline$\beta-\mathrm{HCH}$ & 0.03 & 50.00 & n.d. -0.07 & 0.03 & 33.33 & n.d. -0.05 & 0.03 & 33.33 & n.d. -0.09 & & \\
\hline$\gamma-\mathrm{HCH}$ & 0.06 & 41.67 & n.d. -0.08 & 0.08 & 16.67 & n.d. -0.09 & 0.04 & 33.33 & n.d. -0.07 & & \\
\hline$\delta-\mathrm{HCH}$ & n.d & n.d. & n.d. & n.d. & n.d. & n.d. & n.d. & n.d. & n.d. & & \\
\hline$\sum \mathrm{HCH}$ & 0.03 & 66.67 & n.d. -0.13 & 0.04 & 50.00 & n.d. -0.09 & 0.05 & 50.00 & n.d. -0.12 & & \\
\hline Heptachlor & n.d. & n.d. & n.d. & n.d. & n.d. & n.d. & n.d. & n.d. & n.d. & & \\
\hline Aldrin & n.d. & n.d. & n.d. & n.d. & n.d. & n.d. & n.d. & n.d. & n.d. & & \\
\hline Dieldrin & 2.46 & $91.67^{*}$ & n.d. -5.25 & $0.77^{*}$ & 58.33 & n.d. - 1.64 & 2.95 & 58.33 & n.d. -6.39 & 0.0048 & \\
\hline Endrin & n.d. & n.d. & n.d. & n.d. & n.d. & n.d. & n.d. & n.d. & n.d. & & \\
\hline Chlordane (trans) & n.d. & n.d. & n.d. & n.d. & n.d. & n.d. & n.d. & n.d. & n.d. & & \\
\hline Chlordane (cis) & n.d. & n.d. & n.d. & n.d. & n.d. & n.d. & n.d. & n.d. & n.d. & & \\
\hline Ecyclodienes & 2.46 & $91.67^{*}$ & n.d. -5.25 & $0.77^{*}$ & 58.33 & n.d. -1.64 & 2.95 & 58.33 & n.d. -6.39 & 0.0048 & \\
\hline$\alpha$-Endosulfan & n.d. & n.d. & n.d. & n.d. & n.d. & n.d. & n.d. & n.d. & n.d. & & \\
\hline$\beta$-Endosulfan & n.d. & n.d. & n.d. & n.d. & n.d. & n.d. & n.d. & n.d. & n.d. & & \\
\hline Endosulfan sulfate & n.d. & n.d. & n.d. & 0.59 & & & n.d. & n.d. & n.d. & & \\
\hline p.p'-DDE & 0.31 & 25.00 & n.d. -0.38 & 0.38 & 8.33 & n.d. -0.38 & $0.55^{*}$ & $83.33^{*}$ & n.d. -9.87 & 0.0008 & $\begin{array}{l}0.0013 / \\
0.0009\end{array}$ \\
\hline p.p'-DDD & n.d. & n.d. & n.d. & 0.37 & 8.33 & n.d. -0.37 & 0.21 & 8.33 & n.d. -0.21 & & \\
\hline p.p $\mathrm{p}^{\prime}-\mathrm{DDT}$ & 0.26 & 25 & n.d. -0.26 & 0.21 & 25 & n.d. -0.22 & $0.34^{*}$ & $58.33^{*}$ & n.d. - 0.56 & 0.0260 & 0.02 \\
\hline$\sum D D T$ & 0.38 & 25.00 & n.d. -0.54 & 0.22 & 25.00 & n.d. -0.96 & $0.62^{*}$ & $91.67^{*}$ & n.d. - 10.22 & 0.0012 & 0.0013 \\
\hline Dicofol & 0.93 & 75.00 & n.d. -8.42 & 0.57 & 41.67 & n.d. -1.08 & 1.07 & 58.33 & n.d. -2.31 & & \\
\hline Mirex & n.d. & n.d. & n.d. & n.d. & n.d. & n.d. & n.d. & n.d. & n.d. & & \\
\hline Metoxychlor & n.d. & n.d. & n.d. & n.d. & n.d. & n.d. & n.d. & n.d. & n.d. & & \\
\hline$\sum \mathrm{OCPS}$ & 3.87 & 100.00 & $0.03-11.75$ & $0.95^{*}$ & 100.00 & $0.02-3.29$ & 4.97 & 100.00 & $0.28-10.76$ & 0.0021 & 0.049 \\
\hline
\end{tabular}

n.d.: Non-detectable.

a Values resulting from the comparison between the medians, referred to the figures with an asterisc (Mann-Whitney test).

${ }^{b}$ Values resulting from the comparison between the frequencies, referred to the figures with an asterisc (Chi-square test). 
fat established by the European authorities that has been surpassed in up to $17 \%$ of the samples analyzed in other recent studies in Europe (Van Overmeire et al., 2006, 2009).

With respect to the rest of OCPs residues detected in our study, dieldrin was the only cyclodiene found, being aldrin, endrin, heptachlor and chlordanes below the detection level (LOD) of our method. Dieldrin was also the OCP residue that we found at the highest concentrations, which could be explained because in the Canary Islands this pesticide was extensively used in the past until it was banned at the beginning of the 80s. Dieldrin has been also the pesticide found at the highest concentrations in other studies performed in this archipelago (Luzardo et al., 2012, 2006). We found that the median values of this pesticide were lower in free-run eggs than in conventionally or organically produced ones (0.77 $\mathrm{ng} \mathrm{g}^{-1}$ fat vs. $2.46 \mathrm{ng} \mathrm{g}^{-1}$ fat and $2.95 \mathrm{ng} \mathrm{g}^{-1}$ fat; $p=0.0048$ ), but its concentrations were much lower than those found in other recent studies (Polder et al., 2010; Van Overmeire et al., 2006). A similar situation was observed for HCB residues in egg yolk composites and also the $\mathrm{HCH}$ isomers (Polder et al., 2010), but in these cases there were no statistically significant differences regarding the production type. Dicofol was also present in our set of samples with high frequency, and at a concentration around $1 \mathrm{ng} \mathrm{g}^{-1}$ fat, with no influence of the production mode on it. This is a residue that is not usually included in the set of analytes measured in food, at least in the studies in eggs, so we cannot compare our results with previous studies, but this pesticide has been found in wild bird eggs with similar frequency but at higher concentrations (Malik et al., 2011). The presence of this residue with high frequency maybe could be explained by the fact that it was thoroughly used in the cultivation of tropical fruits in the Canary Islands in the past, and also because this pesticide, important since it is a source of DTT, has been produced in Spain until late 2008.

\subsection{Occurrence of $P C B$ residues in egg yolk samples}

Our results demonstrate that commercially available brands of eggs in the markets of the Canary Islands showed quantifiable levels of various PCBs (mean $=8$ ), independently of the form of production employed. Total PCBs ( $\sum 18$ congeners) concentrations ranged from 0.18 to $14.23 \mathrm{ng} \mathrm{g}^{-1}$ fat (median $4.26 \mathrm{ng} \mathrm{g}^{-1}$ fat) in eggs from conventional production. Unlike other studies, we did not found higher values of these contaminants in eggs from hens with outdoor access, and thus the values found in conventionally-produced eggs were similar to those found in eggs from organic production (range from 0.21 to $21.39 \mathrm{ng} \mathrm{g}^{-1}$ fat, median $3.93 \mathrm{ng} \mathrm{g}^{-1} \mathrm{fat}$ ), or even higher than those found in eggs from free-run production (range from 0.0 to $7.91 \mathrm{ng} \mathrm{g}^{-1}$ fat, median $2.07 \mathrm{ng} \mathrm{g}^{-1}$ fat) (Table 2). As also shown in Table 2, a similar pattern of contamination was observed with the $\sum M-P C B s:$ the free-run produced eggs had the lowest levels, and no differences were found between organic and conventional production. But when we observed the individual congeners by type of production we found that the organically produced had a higher frequency of PCB congeners 52 and 101, which were not detected in none of the composites of conventionally produced or free-run eggs. This difference could be in relation with the consumption by free ranging hens with access to soil of additional feed sources, such as noncommercial feeds, worms and other insects, and soil (Rawn et al., 2012). In none of the samples levels surpassed the EC level of $40 \mathrm{ng} \mathrm{g}^{-1}$ fat for M-PCBs (EC, 2011).

It is difficult to compare the results of $\sum P C B$ s with other studies because a different number of congeners have been measured in each of them. More comparable are the results of M-PCBs that have been homogeneously determined in different studies all over the world. When compared with the most recent series, our results

Table 2

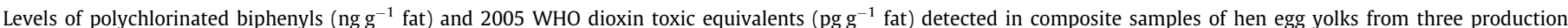
methods $(n=12 /$ each $)$.

\begin{tabular}{|c|c|c|c|c|c|c|c|c|c|c|c|}
\hline \multirow[t]{2}{*}{ Compound } & \multicolumn{3}{|c|}{ Conventional production } & \multicolumn{3}{|c|}{ Free-run production } & \multicolumn{3}{|c|}{ Organic production } & \multirow[t]{2}{*}{$P^{\mathrm{a}}$} & \multirow[t]{2}{*}{$P^{\mathrm{b}}$} \\
\hline & $\begin{array}{l}\text { Median } \\
\left(\mathrm{ng} \mathrm{g}^{-1}\right)\end{array}$ & $\begin{array}{l}\text { Frequency } \\
(\%)\end{array}$ & $\begin{array}{l}\text { Detection } \\
\text { range }\left(\mathrm{ng} \mathrm{g}^{-1}\right)\end{array}$ & $\begin{array}{l}\text { Median } \\
\left(\mathrm{ng} \mathrm{g}^{-1}\right)\end{array}$ & $\begin{array}{l}\text { Frequency } \\
(\%)\end{array}$ & $\begin{array}{l}\text { Detection } \\
\text { range }\left(\mathrm{ng} \mathrm{g}^{-1}\right)\end{array}$ & $\begin{array}{l}\text { Median } \\
\left(\mathrm{ng} \mathrm{g}^{-1}\right)\end{array}$ & $\begin{array}{l}\text { Frequency } \\
(\%)\end{array}$ & $\begin{array}{l}\text { Detection } \\
\text { range }\left(\mathrm{ng} \mathrm{g}^{-1}\right)\end{array}$ & & \\
\hline \multicolumn{12}{|l|}{ Marker PCBs } \\
\hline PCB 28 & 1.04 & 83.33 & n.d. - 1.72 & $0.59^{*}$ & $33.33^{*}$ & n.d. -0.80 & 0.78 & 66.67 & n.d. - 1.75 & 0.0012 & 0.038 \\
\hline PCB 52 & n.d. & n.d. & n.d. & n.d. & n.d. & n.d. & 0.64 & 8.33 & n.d. -0.64 & & \\
\hline РСВ 101 & n.d. & n.d. & n.d. & n.d. & n.d. & n.d. & 0.96 & 16.67 & n.d. -1.17 & & \\
\hline РСВ 138 & 0.87 & 33.33 & n.d. - 1.04 & 0.90 & 16.67 & n.d. -0.93 & 0.91 & 25.00 & n.d. - 1.12 & & \\
\hline РСВ 153 & 0.75 & 58.33 & $0.12-1.40$ & 0.89 & 41.67 & n.d. -2.35 & 0.64 & 66.67 & $0.16-2.67$ & & \\
\hline РCB 180 & 0.72 & 41.67 & $0.14-1.46$ & 0.62 & 33.33 & n.d. -2.19 & 1.16 & 33.33 & $0.11-1.16$ & & \\
\hline$\sum \mathrm{M}-\mathrm{PCBs}$ & 1.85 & 100.00 & $0.18-5.87$ & 0.56 & 91.67 & n.d. -6.01 & 1.22 & 100.00 & $0.21-6.50$ & 0.0009 & \\
\hline \multicolumn{12}{|c|}{ Dioxin-like PCBs } \\
\hline РCB 77 & n.d. & n.d. & n.d. & n.d. & n.d. & n.d. & n.d. & n.d. & n.d. & & \\
\hline РСВ 81 & n.d. & n.d. & n.d. & n.d. & n.d. & n.d. & n.d. & n.d. & n.d. & & \\
\hline РСВ 105 & 1.51 & 58.33 & n.d. - 3.51 & 1.05 & 33.33 & n.d. -1.36 & 1.31 & 50.00 & n.d. -4.05 & & \\
\hline РСВ 114 & n.d. & n.d. & n.d. & n.d. & n.d. & n.d. & n.d. & n.d. & n.d. & & \\
\hline PCB 118 & 1.65 & 83.33 & n.d. -5.02 & 1.25 & 66.67 & n.d. -2.28 & 2.01 & 83.33 & n.d. -10.39 & & \\
\hline РСВ 123 & n.d. & n.d. & n.d. & n.d. & n.d. & n.d. & n.d. & n.d. & n.d. & & \\
\hline РСВ 126 & n.d. & n.d. & n.d. & 0.56 & 8.33 & n.d. -0.56 & 0.67 & 8.33 & n.d. -0.67 & & \\
\hline РСВ 156 & 0.74 & 33.33 & n.d. -1.08 & n.d. & n.d. & n.d. & 0.53 & 25.00 & n.d. -0.53 & & \\
\hline РCВ 157 & 0.73 & 16.67 & n.d. -0.80 & n.d. & n.d. & n.d. & n.d. & n.d. & n.d. & & \\
\hline РСB 167 & n.d. & n.d. & n.d. & n.d. & n.d. & n.d. & n.d. & n.d. & n.d. & & \\
\hline РСВ 169 & n.d. & n.d. & n.d. & n.d. & n.d. & n.d. & n.d. & n.d. & n.d. & & \\
\hline РСВ 180 & n.d. & n.d. & n.d. & n.d. & n.d. & n.d. & n.d. & n.d. & n.d. & & \\
\hline$\sum \mathrm{DL}-\mathrm{PCBS}$ & 2.45 & 83.33 & n.d. - 9.62 & $1.40^{*}$ & 75.00 & n.d. -3.50 & 2.40 & 91.67 & n.d. - 14.89 & 0.032 & \\
\hline$\sum \mathrm{PCBs}$ & 4.26 & 100.00 & $0.18-14.23$ & $2.07^{*}$ & 91.67 & n.d. - 7.91 & 3.93 & 100.00 & $0.21-21.39$ & 0.045 & \\
\hline $\begin{array}{c}\sum \text { TEQ }_{\text {DIOXIN- }} \\
\text { LIKE PCBs }\end{array}$ & 0.07 & 83.33 & n.d. -0.29 & 0.04 & 75.00 & n.d. -56.58 & 0.09 & 91.67 & n.d. - 67.94 & & \\
\hline
\end{tabular}

n.d.: Non-detectable.

a Values resulting from the comparison between the medians, referred to the figures with an asterisc (Mann-Whitney test).

b Values resulting from the comparison between the frequencies, referred to the figures with an asterisc (Chi-square test). 
were slightly higher than those found in Canada in 2012 (Rawn et al., 2012), but slightly lower than those found in other studies done in Spanish regions: Catalonia in 2002 and 2003 (Eljarrat et al., 2002; Llobet et al., 2003), and Andalusia in 2004 (Bordajandi et al., 2004). Much more important were the differences found with studies from Central and East Europe, where the values found for these contaminants were 30 -fold or higher than in our samples (Polder et al., 2010; Van Overmeire et al., 2006; Windal et al., 2009). It is a known fact that the levels of contamination by POPs of the different territories can be enormously different depending on many factors, and we have to take into account that the Canary Islands, where this study was performed, is a relatively non-industrialized region were a low level of contamination for these compounds is expected.

According to literature, background toxic equivalent quantity (TEQ) levels for dioxin-like PCBs in commercially available eggs calculated using the toxic equivalency factors (TEFs) determined in 2005 (Van den Berg et al., 2006), ranged from 0.089 to $12.8 \mathrm{pg} \mathrm{TEQ} \mathrm{g}^{-1}$ fat (Bordajandi et al., 2004; Darnerud et al., 2006; Eljarrat et al., 2002; Llobet et al., 2003; Polder et al., 2010; Rawn et al., 2012). In our study, the results have been found to be in the lower bound of this range, being the median values of $0.07 \mathrm{pg} \mathrm{TEQ} \mathrm{g}^{-1}$ fat, $0.04 \mathrm{pg} \mathrm{TEQ} \mathrm{g}^{-1}$ fat and $0.09 \mathrm{pg} \mathrm{TEQ} \mathrm{g}^{-1}$ fat for conventionally-produced, free-run and organic eggs, respectively. Nevertheless, we have to remark the worrying result that two yolk composites, one free-run and one organic, greatly exceeded the current European Commission limit of 5 pg TEQ $\mathrm{PCDD} / \mathrm{F}+\mathrm{DL}-\mathrm{PCB} \mathrm{g}^{-1}$ fat (EC, 2011) because of their high content in PCB 126, being the rest well below of this limit. This represents about a $5 \%$ of the analyzed samples in our study, which is in agreement with the reports of European researchers who have found that between 5\% and 25\% of the eggs produced under free-range or other alternative production types have PCDD/F and DL-PCBs that exceed the EC limits (Darnerud et al., 2006; De Vries et al., 2006).

\subsection{Occurrence of PAH residues in egg yolk samples}

In spite of the fact that the recent evaluation of the European Food Safety Agency (EFSA) of PAHs presence in food commodities did not included eggs (EFSA, 2008), we decided to investigate their presence in this important food supply since it has been proven that cereals, the main ingredient of the feed of laying hens, can be contaminated with important levels of these hydrocarbons (EFSA, 2008), and that an efficient transfer exist of these compounds from the food to the lipidic fraction of the eggs (Fournier et al., 2010). The same than other previous studies (Falco et al., 2003), we have included those 16 PAHs initially considered by the Environmental Protection Agency (EPA) as priority contaminants due to their potential toxicity.

Our results show that in conventionally produced egg composites 10 of 16 PAHs were present, being naphthalene, phenanthrene, fluoranthene and pyrene detectable in $100 \%$ of the samples (Table 3), reaching these compounds also the highest concentrations. In free-run and organic eggs these were also the most frequently detected compounds and also found at the highest levels, but regarding the concentrations it is interesting to note that in general the levels found in organic eggs were approximately the half or the third part than those found for the same contaminants in conventionally produced eggs, and that these levels were even lower for most of them in free-run eggs (Table 3). Nevertheless, as also can be seen in Table 3, in a high percentage of samples from these two alternative methods of producing eggs the contaminants acenaphthene and the highly carcinogenic benzo[ $a$ ]pyrene were detected, whereas none of these two were found in conventionally produced eggs. We did not detect acenaphtylene, anthracene, indeno[1,2,3-c,d]pyrene and dibenzo[ $a, h]$ anthracene in none of the samples. In other studies these compounds have been found in egg samples but with low frequency and at the lowest concentrations of all the 16 compounds measured (Falco et al., 2003; Veyrand et al., 2013). Differences in extraction and/or analytical methods may explain such differences.

We compared the median values of $\sum 16$ PAHs obtained for the three groups and the differences found for individual compounds as regards to the production type were maintained, being more than double in conventionally produced eggs than in free-run and organic eggs (496.26 $\mathrm{ng} \mathrm{g}^{-1}$ fat vs. $172.14 \mathrm{ng} \mathrm{g}^{-1}$ fat and $238.98 \mathrm{ng} \mathrm{g}^{-1}$ fat, respectively). Following the EFSA recommendations we also compared the median values of the sum of those 8 compounds for which there are evidences of carcinogenicity and genotoxicity (EFSA, 2008) and the pattern was repeated, being

Table 3

Levels of polycyclic aromatic hydrocarbons ( $\left.\mathrm{ng} \mathrm{g}^{-1} \mathrm{fat}\right)$ detected in composite samples of hen egg yolks from three production methods $(n=12 /$ each).

\begin{tabular}{|c|c|c|c|c|c|c|c|c|c|c|}
\hline \multirow[t]{2}{*}{ Compound } & \multicolumn{3}{|c|}{ Conventional production } & \multicolumn{3}{|c|}{ Free-run production } & \multicolumn{3}{|c|}{ Organic production } & \multirow[t]{2}{*}{$P^{\mathrm{a}}$} \\
\hline & $\begin{array}{l}\text { Median } \\
\left(\mathrm{ng} \mathrm{g}^{-1}\right)\end{array}$ & $\begin{array}{l}\text { Frequency } \\
(\%)\end{array}$ & $\begin{array}{l}\text { Detection } \\
\text { range }\left(\mathrm{ng} \mathrm{g}^{-1}\right)\end{array}$ & $\begin{array}{l}\text { Median } \\
\left(\mathrm{ng} \mathrm{g}^{-1}\right)\end{array}$ & $\begin{array}{l}\text { Frequency } \\
(\%)\end{array}$ & $\begin{array}{l}\text { Detection } \\
\text { range }\left(\mathrm{ng} \mathrm{g}^{-1}\right)\end{array}$ & $\begin{array}{l}\text { Median } \\
\left(\mathrm{ng} \mathrm{g}^{-1}\right)\end{array}$ & $\begin{array}{l}\text { Frequency } \\
(\%)\end{array}$ & $\begin{array}{l}\text { Detection } \\
\text { range }\left(\mathrm{ng} \mathrm{g}^{-1}\right)\end{array}$ & \\
\hline Naphtalene & $147.49^{*}$ & 100.00 & $50.01-286.31$ & 23.69 & 33.33 & n.d. -23.69 & 59.24 & 50.00 & n.d. -132.76 & 0.0008 \\
\hline Acenaphtylene & n.d. & n.d. & n.d. & n.d. & n.d. & n.d. & n.d. & n.d. & n.d. & \\
\hline Acenaphthene & n.d. & n.d. & n.d. & $15.95^{*}$ & 66.67 & n.d. -24.32 & $20.82^{*}$ & 16.67 & n.d. -21.79 & 0.0012 \\
\hline Fluorene & $12.64^{*}$ & 50.00 & n.d. - 23.87 & 7.96 & 8.33 & n.d. - 7.96 & 6.54 & 8.33 & n.d. -6.54 & 0.018 \\
\hline Phenanthrene & $200.80^{*}$ & 100.00 & $71.78-549.00$ & 63.02 & 100.00 & $28.71-121.65$ & 115.26 & 100.00 & $68.96-319.20$ & 0.0009 \\
\hline Anthracene & n.d. & n.d. & n.d. & n.d. & n.d. & n.d. & n.d. & n.d. & n.d. & \\
\hline Fluoranthene & $79.16^{*}$ & 100.00 & $33.26-195.96$ & 28.54 & 83.33 & n.d. -46.29 & 34.09 & 83.33 & n.d. - 108.67 & 0.0022 \\
\hline Pyrene & $82.05^{*}$ & 100.00 & $25.74-141.49$ & 42.24 & 91.67 & n.d. -80.30 & 59.92 & 100.00 & $15.30-152.18$ & 0.050 \\
\hline Benz[a]anthracene & $36.75^{*}$ & 41.67 & n.d. - 127.23 & 8.68 & 8.33 & n.d. -8.68 & 7.70 & 25.00 & n.d. - 21.27 & 0.036 \\
\hline Chrysene & 21.81 & 50.00 & n.d. -154.34 & 19.41 & 25.00 & n.d. -25.89 & 17.97 & 25.00 & n.d. -30.57 & \\
\hline Benzo[b]fluoranthene & 12.51 & 75.00 & n.d. -32.30 & $9.67^{*}$ & 33.33 & n.d. -14.61 & 13.29 & 16.67 & n.d. -15.55 & \\
\hline Benzo[k]fluoranthene & 12.86 & 58.33 & n.d. -30.08 & 8.42 & 33.33 & n.d. - 11.87 & 12.19 & 16.67 & n.d. -13.42 & \\
\hline Benzo[a]pyrene & n.d & n.d. & n.d. & $11.03^{*}$ & 66.67 & n.d. -13.33 & $10.51^{*}$ & 58.33 & n.d. -58.33 & 0.0011 \\
\hline $\begin{array}{l}\text { Indeno[1.2.3- } \\
\text { c.d]pyrene }\end{array}$ & n.d. & n.d. & n.d. & n.d. & n.d. & n.d. & n.d. & n.d. & n.d. & \\
\hline Dibenzo[a.h]anthracene & n.d. & n.d. & n.d. & n.d. & n.d. & n.d. & n.d. & n.d. & n.d. & \\
\hline Benzo[g.h.i]perylene & 24.91 & 8.33 & n.d. - 24.91 & n.d. & n.d. & n.d. & n.d. & n.d. & n.d. & \\
\hline$\sum \mathrm{PAHs}$ & 496.29 & 100.00 & $88.91-1521.69$ & 172.14 & 100.00 & $50.70-315.80$ & 238.98 & 100.00 & $95.66-620.22$ & 0.0009 \\
\hline$\sum \mathrm{PAH} 8$ & 65.95 & 75.00 & n.d. - 368.86 & 18.47 & 75.00 & n.d. - 65.71 & 31.29 & 66.67 & n.d. - 65.63 & 0.0007 \\
\hline
\end{tabular}

n.d.: Non-detectable.

a Values resulting from the comparison between the medians, referred to the figures with an asterisc (Mann-Whitney test), in comparison with the other two groups, from left ro right. 
the conventionally produced eggs those with the highest levels (65.95 $\mathrm{ng} \mathrm{g}^{-1}$ fat vs. $18.47 \mathrm{ng} \mathrm{g}^{-1}$ fat and $31.29 \mathrm{ng} \mathrm{g}^{-1}$ fat for conventional, free-run and organic eggs respectively). It is necessary to take into account that in high egg consumers these estimates would be doubled. Our results are similar to others recently found (Veyrand et al., 2013) but we have to say that we can only compare our results obtained for conventionally produced eggs since no studies have been done in eggs from other alternative production methods. To our knowledge this is the first time in which the incidence of the production method of the eggs on the PAHs content is described. The factors that could explain why the conventionally produced eggs have a significantly higher level of PAHs are not known, but probably have to do with the content of the contaminants in the feed used in this production type as compared to that used in the alternative ones. Anyway, we can only speculate with this and more research should be done in order to clarify this aspect.

\subsection{Dietary intakes}

Dietary exposure calculations are done by combining data on consumption habits with the concentrations of contaminants found in food samples. In this study the consumption habits data used were from the Canary Islands Nutrition Survey 1998-1999 (Serra Majem et al., 2000) and the dietary intake was calculated by multiplying the concentration value of each contaminant in each of the three classes of eggs by the daily consumption of this food (in $g$ egg fat/day), and dividing by the average weight of the people in each segment of age. In Table 4 we have summarized the dietary intakes of all the contaminants included in this study arranged by groups, for children (6-10 years), youngsters (1117 years), and adults ( $>18$ years), and considering three potential scenarios: (a) consumers that choose conventionally produced eggs; (b) consumers that choose eggs from free-run eggs; and (c) consumers that choose organic eggs.

Our results show that the egg-related estimated daily intake (EDI) of OCPs for people living in the Canary Islands is extremely low in all the segments of age, representing in all the cases less than $0.01 \%$ of the tolerable daily intakes (TDIs) established by the World Health Organization for these contaminants (JMPR, 2000), and the level of exposure of this population through this food is lower than estimates recently published for other European populations (Darnerud et al., 2006; Polder et al., 2010; Van Overmeire et al., 2006). Except for the case of $\sum D D T$ no relevant differ- ences were found as regards to the production method. Unlike other studies we have not found higher levels of exposure for most OCPs in those consumers that choose free-range eggs, and even these types of egg showed a tendency of lower intake levels in our study. In the case of DDT and its metabolites a higher level of exposure from organic eggs consumption was observed, but the highest level of exposure calculated (children $=0.054 \mathrm{ng} \mathrm{kg}^{-1}$ b.w. $\mathrm{d}^{-1}$ ) was very far from the TDI of $1000 \mathrm{ng} \mathrm{kg}^{-1}$ b.w. $\mathrm{d}^{-1}$ established for this pesticide (JMPR, 2000; Lu, 1995).

As shown in Table 4, PCBs intake estimates were very similar in conventionally produced, free-run, and organic eggs. Unlike the rest of the contaminants included in this study, when we consider the intake of the most toxic compounds, the DL-PCBs, expressed in terms of equivalency to dioxin toxicity, our estimations would vary dramatically depending on the approach chosen for the calculations. If we had chosen the lower bound approach we may say that the eggs do not represent an important source for these contaminants, independently of the type of production nor the age segment. Using this approach, our estimates of $\sum$ TEQS $S_{P C B s}$ in the highest mean value of intake (children that consume organic eggs $=0.008 \mathrm{pg} \mathrm{kg}^{-1}$ b.w. $\mathrm{d}^{-1}$ ) would represent only $0.4 \%$ of the TDI of $2 \mathrm{pg} \mathrm{kg}^{-1}$ b.w. $\mathrm{d}^{-1}$ (SCF, 2000). Nevertheless, as recommended by the European Commission, in the dietary intake calculations it is necessary to apply the upper bound method in order to compare with the established TDIs. In this case our estimates would be 60 times higher, and therefore the exposure through egg consumption would represent as much as $24 \%$ of TDI. This enormous difference depending on the upper/lower bound approaches represents an important limitation of this methodology in this case, and the interpretation of these estimates should be taken with caution. Therefore we have not introduced intake estimation of $\sum T_{E Q s_{\text {DL-PCBs }}}$ in Table 4 . In any case, regardless of the approach used, we would like to highlight the fact that about a $5 \%$ of the samples ( 2 out 36 composites analyzed), if were inadvertently consumed, would have represented an important intake of dioxin-like compounds, because of their high content in PCB 126, which is in accordance to other studies where authors have estimated that eggs are an important source of dioxins and dioxin-like compounds in more of $10 \%$ of the samples analyzed (Van Overmeire et al., 2009). These results are extremely worrisome and further studies are required to clarify the origin of egg contamination, because the possibility exists that certain consumers may be subjected to a high dietary exposure to dioxins.

Table 4

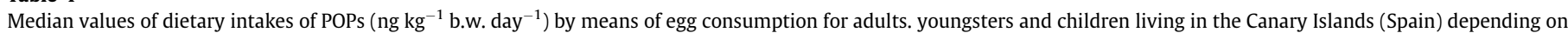
the egg's production method chosen.

\begin{tabular}{|c|c|c|c|c|c|c|c|c|c|}
\hline \multirow[t]{2}{*}{ Compound } & \multicolumn{3}{|c|}{ Conventional production } & \multicolumn{3}{|c|}{ Free-run production } & \multicolumn{3}{|c|}{ Organic production } \\
\hline & Adults & Youngsters & Children & Adults & Youngsters & Children & Adults & Youngsters & Children \\
\hline \multicolumn{10}{|l|}{ OCPS } \\
\hline$\sum \mathrm{HCH}$ & 0.001 & 0.002 & 0.002 & 0.002 & 0.003 & 0.003 & 0.002 & 0.004 & 0.005 \\
\hline$\sum$ Cyclodienes & 0.105 & 0.177 & 0.233 & 0.036 & 0.055 & 0.068 & 0.139 & 0.219 & 0.288 \\
\hline$\sum$ DDTs & 0.017 & 0.027 & 0.036 & 0.011 & 0.017 & 0.021 & 0.028 & 0.046 & 0.060 \\
\hline$\sum \mathrm{OCPs}$ & 0.180 & 0.284 & 0.364 & 0.044 & 0.068 & 0.092 & 0.201 & 0.309 & 0.407 \\
\hline \multicolumn{10}{|l|}{ PCBs } \\
\hline$\sum \mathrm{M}-\mathrm{PCBs}$ & 0.127 & 0.200 & 0.262 & 0.037 & 0.060 & 0.081 & 0.083 & 0.130 & 0.173 \\
\hline$\sum \mathrm{DL}-\mathrm{PCBs}$ & 0.160 & 0.252 & 0.332 & 0.092 & 0.139 & 0.188 & 0.123 & 0.188 & 0.258 \\
\hline$\sum \mathrm{PCBs}$ & 0.211 & 0.357 & 0.451 & 0.138 & 0.214 & 0.275 & 0.195 & 0.303 & 0.389 \\
\hline$\sum \mathrm{TEQS}_{\mathrm{PCBS}}^{\mathrm{a}}{ }^{\mathrm{a}, \mathrm{b}}$ & 0.003 & 0.005 & 0.006 & 0.002 & 0.003 & 0.004 & 0.004 & 0.006 & 0.008 \\
\hline \multicolumn{10}{|l|}{ PAHs } \\
\hline$\sum \mathrm{PAH8}$ & 2.418 & 4.539 & 5.971 & 0.757 & 1.371 & 1.842 & 1.223 & 2.312 & 2.832 \\
\hline$\sum \mathrm{PAHs}$ & 22.672 & 34.81 & 47.074 & 7.506 & 12.073 & 15.734 & 10.719 & 17.075 & 22.255 \\
\hline
\end{tabular}

\footnotetext{
${ }^{\mathrm{a}}$ Values expressed in $\mathrm{pg} \mathrm{kg}^{-1}$ b.w. day ${ }^{-1}$.
}

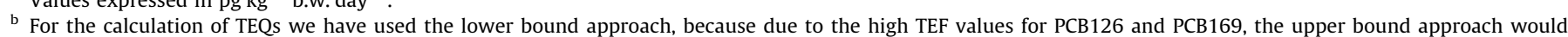
introduce an overestimation higher than 60X. 
Finally, as also shown in Table 4, the daily intake of PAHs greatly depended on the type of eggs chosen. When the consumers choose eggs from free-run hens their intake of $\sum$ PAHs is near three times lower than if conventionally produced eggs are consumed. Also the consumption of organic eggs implies an evident lower intake of these contaminants. These differences are even greater when only the carcinogenic PAHs ( $\mathrm{PPAH} 8$ ) are considered. When compared with the most recently published data, the second French total diet study (Veyrand et al., 2013), our estimations of intake for PAHs from conventional eggs were very similar to that study in adults ( $\sum$ PAH8 $=2.739$ vs. $2.281 \mathrm{ng} \mathrm{kg}^{-1}$ b.w. $\mathrm{d}^{-1}$ ) but almost double in children ( $\sum$ PAH8 $=5.687$ vs. $3.493 \mathrm{ng} \mathrm{kg}^{-1}$ b.w. $\mathrm{d}^{-1}$ ). This is due to the different pattern of consumption of eggs of children from both populations. Nevertheless, until this moment no estimates have been done regarding the intake of PAHs coming from eggs of alternative production methods. Therefore, this study represents the first evidence that consumption of organic eggs or eggs from hens with outdoor access can be a way to reduce the daily intake of these carcinogenic contaminants of food.

\section{Conclusion}

Unlike the observations in European studies and in accordance to the measurements done in Canada, OCPs and PCBs residues were not significantly higher in free-range eggs yolks. The levels of contamination by these organochlorine compounds in the $100 \%$ of the eggs of this study, all of them locally produced, were extremely low and none of the samples surpassed the MRLs established in the EU. Therefore the level of exposure of the inhabitants of the archipelago is well below the established TDIs and we could consider that the contribution of eggs to the total daily intake is negligible. However, it is possible that consumers are unwittingly exposed to high levels of dioxin-like compounds through consumption of eggs, since our results show that the TDI had been largely overcome if $5 \%$ of the samples, with high concentrations PCB 126, had been consumed. Finally, it is very interesting the finding that the consumers that choose eggs from free-ranging hens have a significantly lower intake of carcinogenic PAHs, what is very relevant, especially in children. Therefore, the consumption of organic or free-run eggs can be a good option for reducing the exposure to these carcinogenic contaminants.

\section{Conflict of Interest}

The authors declare that there are no conflicts of interest.

\section{Acknowledgement}

The authors would like to thank to Mrs. María de los Reyes Suárez Hanna for her technical assistance.

\section{References}

Almeida-Gonzalez, M., Luzardo, O.P., Zumbado, M., Rodriguez-Hernandez, A., Ruiz Suarez, N., Sangil, M., Camacho, M., Henriquez-Hernandez, L.A., Boada, L.D. 2012. Levels of organochlorine contaminants in organic and conventional cheeses and their impact on the health of consumers: an independent study in the Canary Islands (Spain). Food Chem. Toxicol. 50, 4325-4332.

Bargar, T.A., Scott, G.I., Cobb, G.P., 2001. Maternal transfer of contaminants: case study of the excretion of three polychlorinated biphenyl congeners and technical-grade endosulfan into eggs by white Leghorn chickens (Gallus domesticus). Environ. Toxicol. Chem. 20, 61-67.

Boada, L.D., Zumbado, M., Henriquez-Hernandez, L.A., Almeida-Gonzalez, M. Alvarez-Leon, E.E., Serra-Majem, L., Luzardo, O.P., 2012. Complex organochlorine pesticide mixtures as determinant factor for breast cancer risk: a population-based case-control study in the Canary Islands (Spain). Environ. Health 11, 28.

Bordajandi, L.R., Gomez, G., Abad, E., Rivera, J., Del Mar Fernandez-Baston, M. Blasco, J., Gonzalez, M.J., 2004. Survey of persistent organochlorine contaminants (PCBs, PCDD/Fs, and PAHs), heavy metals ( $\mathrm{Cu}, \mathrm{Cd}, \mathrm{Zn}, \mathrm{Pb}$, and $\mathrm{Hg}$ ), and arsenic in food samples from Huelva (Spain): levels and health implications. J. Agric. Food Chem. 52, 992-1001.

Camacho, M., Boada, L.D., Oros, J., Calabuig, P., Zumbado, M., Luzardo, O.P., 2012. Comparative study of polycyclic aromatic hydrocarbons (PAHs) in plasma of Eastern Atlantic juvenile and adult nesting loggerhead sea turtles (Caretta caretta). Mar. Pollut. Bull. 64, 1974-1980.

Camacho, M., Luzardo, O.P., Boada, L.D., Lopez Jurado, L.F., Medina, M., Zumbado, M., Oros, J., 2013. Potential adverse health effects of persistent organic pollutants on sea turtles: evidences from a cross-sectional study on Cape Verde loggerhead sea turtles. Sci. Total Environ. 16 (1), 283-289.

Casals-Casas, C., Desvergne, B., 2011. Endocrine disruptors: from endocrine to metabolic disruption. Annu. Rev. Physiol. 73, 135-162.

Darnerud, P.O., Atuma, S., Aune, M., Bjerselius, R., Glynn, A., Grawe, K.P., Becker, W., 2006. Dietary intake estimations of organohalogen contaminants (dioxins, $\mathrm{PCB}$, PBDE and chlorinated pesticides, e.g. DDT) based on Swedish market basket data. Food Chem. Toxicol. 44, 1597-1606.

De Vries, M., Kwakkel, R.P., Kijlstra, A., 2006. Dioxins in organic eggs: a review. NJAS Wageningen J. Life Sci. 54, 207-222.

Dickerson, S.M., Cunningham, S.L., Patisaul, H.B., Woller, M.J., Gore, A.C., 2011. Endocrine disruption of brain sexual differentiation by developmental PCB exposure. Endocrinology 152, 581-594.

Dorgan, J.F., Brock, J.W., Rothman, N., Needham, L.L., Miller, R., Stephenson Jr., H.E., Schussler, N., Taylor, P.R., 1999. Serum organochlorine pesticides and PCBs and breast cancer risk: results from a prospective analysis (USA). Cancer Causes Control 10, 1-11.

EC, 2005. Comission Regulation (EC) No 396/2005 of 23 February 2005 on maximum residue levels of pesticides in or on food and feed of plat and animal origin and amending Council Directive 91/414/EEC.

EC, 2011. Comission REGULATION (EC) No 1259/2011 of 2 December 2011 amending Regulation (EC) No $1881 / 2006$ as regards maximum levels for dioxins, dioxin-like PCBs and non dioxin-like PCBs in foodstuffs. Off. J. Eur. Union L320, 318-323.

EFSA, 2008. Polycyclic aromatic hydrocarbons in food. scientific opinion of the panel on contaminants in the food chain. EFSA J. 724, 1-114.

Eljarrat, E., Monjonell, A., Caixach, J., Rivera, J., 2002. Toxic potency of polychlorinated dibenzo-p-dioxins, polychlorinated dibenzofurans, and polychlorinated biphenyls in food samples from Catalonia (Spain). J. Agric. Food Chem. 50, 1161-1167.

EN, 1996a. European Norm 1528-2. Fatty food - determination of pesticides and polychlorinated biphenyls (PCBs) - Part 2: Extraction of fat, pesticides and PCBs, and determination of fat content. European Commitee for Standardization.

EN, 1996b. European Norm 1528-3. Fatty food. Determination of pesticides and polychlorinated biphenyls (PCBs). Clean-up methods. European Commitee for Standardization.

Falco, G., Domingo, J.L., Llobet, J.M., Teixido, A., Casas, C., Muller, L., 2003. Polycyclic aromatic hydrocarbons in foods: human exposure through the diet in Catalonia, Spain. J. Food Prot. 66, 2325-2331.

Fournier, A., Feidt, C., Dziurla, M.A., Grandclaudon, C., Jondreville, C., 2010. Transfer kinetics to egg yolk and modeling residue recovered in yolk of readily metabolized molecules: polycyclic aromatic hydrocarbons orally administered to laying hens. Chemosphere 78, 1004-1010.

Fournier, A., Feidt, C., Travel, A., Bizec, B.L., Venisseau, A., Marchand, P., Jondreville, C., 2012. Relative bioavailability to laying hens of indicator polychlorobiphenyls present in soil. Chemosphere 88, 300-306.

Hsu, J.F., Chen, C., Liao, P.C., 2010. Elevated PCDD/F levels and distinctive PCDD/F congener profiles in free range eggs. J. Agric. Food Chem. 58, 7708-7714.

JMPR, 2000. Joint FAO/WHO meetings on pesticide residues 2000. Expert Commitee on Food Additives, FAO Plant Production and Protection Paper 163/59 JEFCA 5, 28.

Kijlstra, A., Traag, W.A., Hoogenboom, L.A., 2007. Effect of flock size on dioxin levels in eggs from chickens kept outside. Poult. Sci. 86, 2042-2048.

Knerr, S., Schrenk, D., 2006. Carcinogenicity of "non-dioxinlike" polychlorinated biphenyls. Crit. Rev. Toxicol. 36, 663-694.

Llobet, J.M., Bocio, A., Domingo, J.L., Teixido, A., Casas, C., Muller, L., 2003. Levels of polychlorinated biphenyls in foods from Catalonia, Spain: estimated dietary intake. J. Food Prot. 66, 479-484.

Lu, F.C., 1995. A review of the acceptable daily intakes of pesticides assessed by WHO. Regul. Toxicol. Pharmacol. 21, 352-364.

Luzardo, O.P., Goethals, M., Zumbado, M., Alvarez-Leon, E.E., Cabrera, F., SerraMajem, L., Boada, L.D., 2006. Increasing serum levels of non-DDT-derivative organochlorine pesticides in the younger population of the Canary Islands (Spain). Sci. Total Environ. 367, 129-138

Luzardo, O.P., Almeida-Gonzalez, M., Henriquez-Hernandez, L.A., Zumbado, M., Alvarez-Leon, E.E., Boada, L.D., 2012. Polychlorobiphenyls and organochlorine pesticides in conventional and organic brands of milk: occurrence and dietary intake in the population of the Canary Islands (Spain). Chemosphere 88, 307315.

Malik, R.N., Rauf, S., Mohammad, A., Eqani, S.A., Ahad, K., 2011. Organochlorine residual concentrations in cattle egret from the Punjab Province, Pakistan. Environ. Monit. Assess. 173, 325-341.

Marti-Cid, R., Llobet, J.M., Castell, V., Domingo, J.L., 2008. Dietary intake of arsenic, cadmium, mercury, and lead by the population of Catalonia, Spain. Biol. Trace Elem. Res. 125, 120-132.

Mezzetta, S., Cirlini, M., Ceron, P., Tecleanu, A., Caligiani, A., Palla, G., Sansebastiano, G.E., 2011. Concentration of DL-PCBs in fish from market of Parma city (north Italy): estimated human intake. Chemosphere 82, 1293-1300. 
Polder, A., Savinova, T.N., Tkachev, A., Loken, K.B., Odland, J.O., Skaare, J.U., 2010. Levels and patterns of Persistent Organic Pollutants (POPS) in selected food items from Northwest Russia (1998-2002) and implications for dietary exposure. Sci. Total Environ. 408, 5352-5361.

Pussemier, L., Mohimont, L., Huyghebaert, A., Goeyens, L., 2004. Enhanced levels of dioxins in eggs from free range hens; a fast evaluation approach. Talanta 63, 1273-1276.

Rawn, D.F., Sadler, A.R., Quade, S.C., Sun, W.F., Kosarac, I., Hayward, S., Ryan, J.J., 2012. The impact of production type and region on polychlorinated biphenyl (PCB), polychlorinated dibenzo-p-dioxin and dibenzofuran (PCDD/F) concentrations in Canadian chicken egg yolks. Chemosphere 89, 929-935.

Ribas-Fito, N., Sala, M., Kogevinas, M., Sunyer, J., 2001. Polychlorinated biphenyls (PCBs) and neurological development in children: a systematic review. J. Epidemiol. Community Health 55, 537-546.

Samanta, S.K., Singh, O.V., Jain, R.K., 2002. Polycyclic aromatic hydrocarbons: environmental pollution and bioremediation. Trends Biotechnol. 20, 243-248.

SCF, 2000. Opinion of the Scientific Commitee on Food (SCF) on the risk assessment of dioxins and dioxin-like PCBs in food. Update based on new scientific information available since the adoption of the SCF opinion of 22nd November 2000.

Serra Majem, L., Armas Navarro, A., Ribas Barba, L., 2000. Food consumption and food sources of energy and nutrients in Canary Islands (1997-98). Arch. Latinoam. Nutr. 50, 23-33.
Van den Berg, M., Birnbaum, L.S., Denison, M., De Vito, M., Farland, W., Feeley, M., Fiedler, H., Hakansson, H., Hanberg, A., Haws, L., Rose, M., Safe, S., Schrenk, D., Tohyama, C., Tritscher, A., Tuomisto, J., Tysklind, M., Walker, N., Peterson, R.E., 2006. The 2005 World Health Organization reevaluation of human and Mammalian toxic equivalency factors for dioxins and dioxin-like compounds. Toxicol. Sci. 93, 223-241.

Van Overmeire, I., Pussemier, L., Hanot, V., De Temmerman, L., Hoenig, M., Goeyens L., 2006. Chemical contamination of free-range eggs from Belgium. Food Addit Contam. 23, 1109-1122.

Van Overmeire, I., Pussemier, L., Waegeneers, N., Hanot, V., Windal, I., Boxus, L., Covaci, A., Eppe, G., Scippo, M.L., Sioen, I., Bilau, M., Gellynck, X., De Steur, H., Tangni, E.K., Goeyens, L., 2009. Assessment of the chemical contamination in home-produced eggs in Belgium: general overview of the CONTEGG study. Sci. Total Environ. 407, 4403-4410.

Veyrand, B., Sirot, V., Durand, S., Pollono, C., Marchand, P., Dervilly-Pinel, G., Tard, A. Leblanc, J.C., Le Bizec, B., 2013. Human dietary exposure to polycyclic aromatic hydrocarbons: results of the second French Total Diet Study. Environ. Int. 54, 11-17.

Windal, I., Hanot, V., Marchi, J., Huysmans, G., Van Overmeire, I., Waegeneers, N. Goeyens, L., 2009. PCB and organochlorine pesticides in home-produced eggs in Belgium. Sci. Total Environ. 407, 4430-4437. 